\title{
"Basic principles of financial markets regulation and legal aspects of the legislative requirements"
}

\begin{tabular}{|c|c|}
\hline \multirow{6}{*}{ AUTHORS } & Borys Yazlyuk (D https://orcid.org/0000-0002-2078-0644 \\
\hline & R http://www.researcherid.com/rid/G-6532-2017 \\
\hline & Anatoliy Guley iD https://orcid.org/0000-0003-0703-8936 \\
\hline & Ruslan Brukhanskyi iD https://orcid.org/0000-0002-9360-1109 \\
\hline & Hanna Shovkoplias iD https://orcid.org/0000-0003-0313-8606 \\
\hline & Tetiana Shvydka (D http://orcid.org/0000-0002-6152-2705 \\
\hline ARTICLE INFO & $\begin{array}{l}\text { Borys Yazlyuk, Anatoliy Guley, Ruslan Brukhanskyi, Hanna Shovkoplias and } \\
\text { Tetiana Shvydka (2018). Basic principles of financial markets regulation and } \\
\text { legal aspects of the legislative requirements. Investment Management and } \\
\text { Financial Innovations, 15(1), 337-349. doi:10.21511/imfi.15(1).2018.28 }\end{array}$ \\
\hline DOI & http://dx.doi.org/10.21511/imfi.15(1).2018.28 \\
\hline RELEASED ON & Friday, 30 March 2018 \\
\hline RECEIVED ON & Tuesday, 20 February 2018 \\
\hline \multirow[t]{2}{*}{ ACCEPTED ON } & Friday, 16 March 2018 \\
\hline & $(c c) \overline{B Y-N C}$ \\
\hline LICENSE & $\begin{array}{l}\text { This work is licensed under a Creative Commons Attribution-NonCommercial } 4.0 \\
\text { International License }\end{array}$ \\
\hline JOURNAL & "Investment Management and Financial Innovations" \\
\hline ISSN PRINT & $1810-4967$ \\
\hline ISSN ONLINE & $1812-9358$ \\
\hline PUBLISHER & LLC "Consulting Publishing Company "Business Perspectives" \\
\hline FOUNDER & LLC "Consulting Publishing Company "Business Perspectives" \\
\hline
\end{tabular}

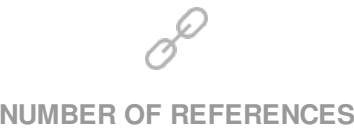

27
NUMBER OF FIGURES

2

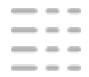

NUMBER OF TABLES

6

(C) The author(s) 2023. This publication is an open access article. 


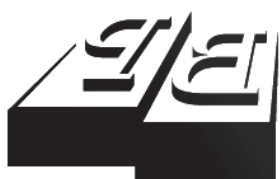

BUSINESS PERSPECTIVES

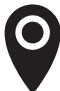

LLC "CPC "Business Perspectives” Hryhorii Skovoroda lane, 10, Sumy, 40022, Ukraine

www.businessperspectives.org

Received on: $20^{\text {th }}$ of February, 2018 Accepted on: $16^{\text {th }}$ of March, 2018

(C) Borys Yazlyuk, Anatoliy Guley, Ruslan Brukhanskyi, Hanna Shovkoplias, Tetiana Shvydka, 2018

Borys Yazlyuk, Doctor of Economics, Professor, Ternopil National Economic University, Ukraine.

Anatoliy Guley, Doctor of Economics, Associate Professor, Chairman of the Executive Board, Interbank Currency Exchange, Ukraine.

Ruslan Brukhanskyi, Doctor of Economics, Professor, Ternopil National Economic University, Ukraine.

Hanna Shovkoplias, Ph.D. (Law), Associate Professor, Yaroslav Mudryi National Law University, Ukraine.

Tetiana Shvydka, Ph.D. (Law), Assistant, Yaroslav Mudryi National Law University, Ukraine.

\section{(ㄷ)(1) (8)}

This is an Open Access article, distributed under the terms of the Creative Commons Attribution-NonCommercial 4.0 International license, which permits re-use, distribution, and reproduction, provided the materials aren't used for commercial purposes and the original work is properly cited.
Borys Yazlyuk (Ukraine), Anatoliy Guley (Ukraine), Ruslan Brukhanskyi (Ukraine), Hanna Shovkoplias (Ukraine), Tetiana Shvydka (Ukraine)

\section{BASIC PRINCIPLES OF FINANCIAL MARKETS REGULATION AND LEGAL ASPECTS OF THE LEGISLATIVE REQUIREMENTS}

\begin{abstract}
Financial services market (FSM) is one of the effective mechanisms for ensuring the competitiveness of the country's economy. It is precisely because of its ability to direct investment flows into the most attractive segments of the economy, and the FSM development can contribute to economic growth. Accordingly, today it is important to strengthen the financial services market in Ukraine. For this purpose, it is necessary to study the current state, identify problems and determine the main directions of its development in a timely manner.
\end{abstract}

The article investigates the financial services market in Ukraine, which is unstable, characterized by a significant outflow of financial resources, and underdeveloped financial intermediaries. FSM deterioration was also influenced by factors such as: financial crisis, sharp exchange rate fluctuations, military conflict, decline of the country's economy, etc. Negative consequences of the events in the country were reflected even in a quite developed banking system. The focus is on the lack of financial culture in society, which is due to low deposit activity, high level of non-repayment of loans, lack of confidence in the new tools, and the introduction of new products in the financial services market. However, the development of the country as a whole is impossible without a strong financial services market.

It is noted that one of the important conditions for the FSM development and the effectiveness of macroeconomic tasks entrusted to it is the formation of an effective mechanism of the financial market state regulation. Such a mechanism should include both elements of state regulation and self-regulation of the financial services market. Accordingly, the formation of indicators aimed at assessing the impact of state regulation on the development of the financial services market becomes relevant.

The article examines the implementation of state regulation in financial services markets, analyzes the activity of the FSM state regulation in Ukraine and the control function effectiveness, considers the dynamics of the main indicators of the financial services markets development in Ukraine, and analyzes the level of financial services markets development.

Keywords control, supervision, financial services market, Ukraine

\section{JEL Classification $\quad$ G18, G20, G21, G23, G28}

\section{INTRODUCTION}

The financial services market (FSM) is the coordinator of the entire financial system, it is the sphere of relations through which financial resources move, and which is a mechanism for increasing the competitiveness of the country's economy. Well-developed legal regulation principles by state regulators are the basis of the financial services market effectiveness.

State regulation of the FSM functioning in Ukraine is characterized by a number of shortcomings, among which the most important are the unclear distribution of state regulators' powers and inconsistency of their competence, the lack of a unified system of influences. 
Supervision and control in the financial services market should be maximally harmonized based on the unity of the capital market and the need to unify operations with financial institutions.

On the way toward the European Community, creating an effective legal mechanism for regulating the financial services market is one of the key tasks of the modern Ukrainian society. Today in Ukraine, FSM shows negative trends of development, which are caused by the complicated conditions of doing business in the financial sector of the country. The tense political situation in Ukraine, instable economic principles of functioning of the whole economic complex, external aggression and a number of other destructive causes resulted in a turbulent environment of financial institutions and the financial services market in general. The outlined reasons do not allow us to form a stable and solid platform for its further development. Such a situation not only requires the FSM research, but also the application of new scientific approaches to assessing the current state of this market.

\section{LITERATURE REVIEW}

To ensure the financial market development as a key sector of the economy and protect its participants, it is important to create an effective mechanism for its regulating. Of particular importance is constructing a system of interconnections between financial institutions in performing their functions, which determines the effectiveness of the financial market functioning.

Many authors considered the issues of state regulation and control over the financial services markets. Blank, Bacho, and Blicharz (2009), Wajda (2009), Wierzbowski and Wiktorowska (2009), Vnukova, Klymenko, Kuznietsova, Levchenko, Masliaieva, Mishchenko, Naumenkova, Poiedynok, Poliukhovych, Prykhodko, Savchenko, and Khodakivska are among them. But today the question of unification of the control and supervision system in the financial services markets is becoming relevant. More importantly, inconsistencies are seen in control and supervision, which are important elements for the formation of common principles of legal regulation in financial services markets.

Siomchenkov and Kuzmenko (2012) emphasize that the necessity of creating an effective mechanism for regulating the financial market was influenced by the global financial crisis, which negatively affected the financial system of the country, in contrast to most of the states that were able to contain negative effects of the crisis. The authors believe that the reason for this was the lack of preparedness of state bodies in a timely manner and to effectively apply the necessary measures of influence.
The analysis of the main approaches to the peculiarities of the state regulation of financial services markets in the EU countries shows the lack of a unified model of state regulation and a large variety of approaches to the competence and powers of the state regulator depending on the country. As Davies (2008) points out, each EU country has its own, distinct, financial regulatory structures.

As the world experience shows, the financial services market is effectively developing when the principle of optimality of state regulation is taken into account: the state regulates the market participants' activities only in cases where it is absolutely necessary, in other cases it delegates some of its powers to professional market participants that are united in self-regulatory organizations (Blyzniuk \& Ivaniuta, 2017).

In world practice, various models of the securities market regulation, depending on the subject of regulation and the degree of regulation rigidity (USAID, 2017), are distinguished. To date, two models of the securities market regulation have successfully operated.

1. Models with the established system of the securities market regulation by state authorities:

- regulation is handled by a separate government body - a commission or agency (United States of America);

- regulation is carried out by a single regulator of the financial market - megacontrol (Germany, Singapore); 
- division of regulatory functions between several departments (UK, Belgium).

2. Models based on the transfer of maximum powers to self-regulatory organizations.

Most authors believe that the most optimal variant for developing the state regulation mechanism in the financial sphere is the creation of a separate megaregulator. The benefits of such a model include: consolidation of responsibility for regulatory activity by one government body, uniform (unified) approach to supervision and regulation of all market participants, simplification and reduction of their reporting, a single information database of financial institutions, etc.

The creation of a mega-regulator can build a powerful center for regulating financial services markets in Ukraine, eliminate the conflict of interest within the National Bank of Ukraine and bring the country to a new level of state regulation of markets.

Some warned about what they called a regulatory avalanche, suggesting that regulations were costly to implement, that complex regulations adversely affected the entry of smaller enterprises into the financial services sector, and that regulators should avoid hasty actions in the wake of crisis. Others emphasized that regulation might be costly but that it was also necessary, and that overall costs of regulation would be less than costs of crises they helped avert. Financial liberalization without proper regulation against external shocks could have far-reaching effects, particularly for developing countries. Hence, there was a need for effective/appropriate regulatory/institutional frameworks. A vibrant financial services market and effective regulation were two sides of the same coin (Report of the expert meeting on trade and development implications of financial services and commodity exchanges).

Particular attention should be paid to the latest state of the global market, fluctuating in functional and institutional aspects, characterized by constant differentiation and diversification of individual segments. The market is not always able to provide an efficient allocation of resources and to produce the required quantity of benefits (Levchenko \& Ostapenko, 2016). Therefore, under economic uncertainty and financial turbulence in the financial services market, it is extremely important to define the effective management indicators.

Every other financial crisis offers its insights into financial market activities. For example, the statutory instrument adopted on July 21, 2010 (Dodd-Frank Wall Street Reform and Consumer Protection Act, 2010) in order to reduce risks of the American financial system, is considered to be the most significant change in US financial regulation since the Great Depression. The law has significantly changed the activities of federal authorities that regulate the financial services provision, as well as created an additional body of financial regulation - the Supervisory Board of Financial Stability.

As a result, the bill, and more precisely Volcker rule, helped solve the main problem of the US banking system in 2008-2011 - to reduce systemic risks that could lead to a recurrence of the 2007-2008 crisis situation. On the other hand, the bill was the main reason why the largest American banks failed to return their capitalization to crisis rates.

If you look at the major issuers of Dow Jones 30 and S\&P500, then almost all companies have reached their historic highs for share value. The American banks, on the contrary, are the only ones who have not been able to reach this mark, unlike individual subjects. Today, American regulators are reviewing changes to Volcker rule.

The European Commission intends to take Volcker rule as a basis for reforming and take measures to restrict high-risk operations of banks using their own funds. Already in 2018, a prohibition on proprietary trade may come into force in the EU for leading European banks. Thus, the regulators want to protect the EU financial system from shocks similar to the 2008 financial crisis.

The purpose of this article is to study the problem areas of regulation in the form of control in financial services markets.

\section{RESEARCH FINDINGS}

One of the main tasks of financial markets state regulation is the distribution of functions of authorized bodies in the financial services markets. 
It is necessary to consider the existing legal regulation of financial services markets within the framework of state regulation. State regulation of financial services markets in Ukraine is ensured through the implementation of the following basic laws and legislative acts: the Law of Ukraine "On Financial Services and State Regulation of Financial Services Markets" No. 2664-III as of July 12, 2001; the Provision "On the National Commission, which carries out state regulation in the field of financial services markets", approved by the Decree of the President of Ukraine No. 1070 dated November 23, 2011; Law of Ukraine "On Securities and Stock Market" No. 3480-IV of February 23, 2006; the Law "On State Regulation of the Securities Market in Ukraine" No. 488 as of October 30, 1996; the Provision "On the National Commission on Securities and Stock market" approved by Decree of the President of Ukraine No. 1063 dated November 23, 2011; the Law "On the National Bank of Ukraine" No. 679 as of May 20, 1999; the Law "On Banks and Banking" No. 2121 of December 7, 2000.
The modern state regulation of the financial services market in Ukraine is provided by three authorized bodies: the National Commission, which carries out state regulation in the field of financial services markets (National Financial Services Commission), the National Securities and Stock Market Commission (NSSMC), and the National Bank of Ukraine (NBU). Also, the regulatory bodies are the Antimonopoly Committee, the State Financial Monitoring Service and the Deposit Guarantee Fund of individuals who do not intend to manage the financial services market, but can exercise and do exercise regulatory powers with respect to them, the nature of which is determined by the functional direction of the body. However, according to Klymenko (2014), as the functioning of these markets testifies, the Antimonopoly Committee of Ukraine does not take an active position on this issue. NBU makes a decision on withdrawal of a banking license and liquidation of the bank on the proposal of the Deposit Guarantee Fund of individuals.

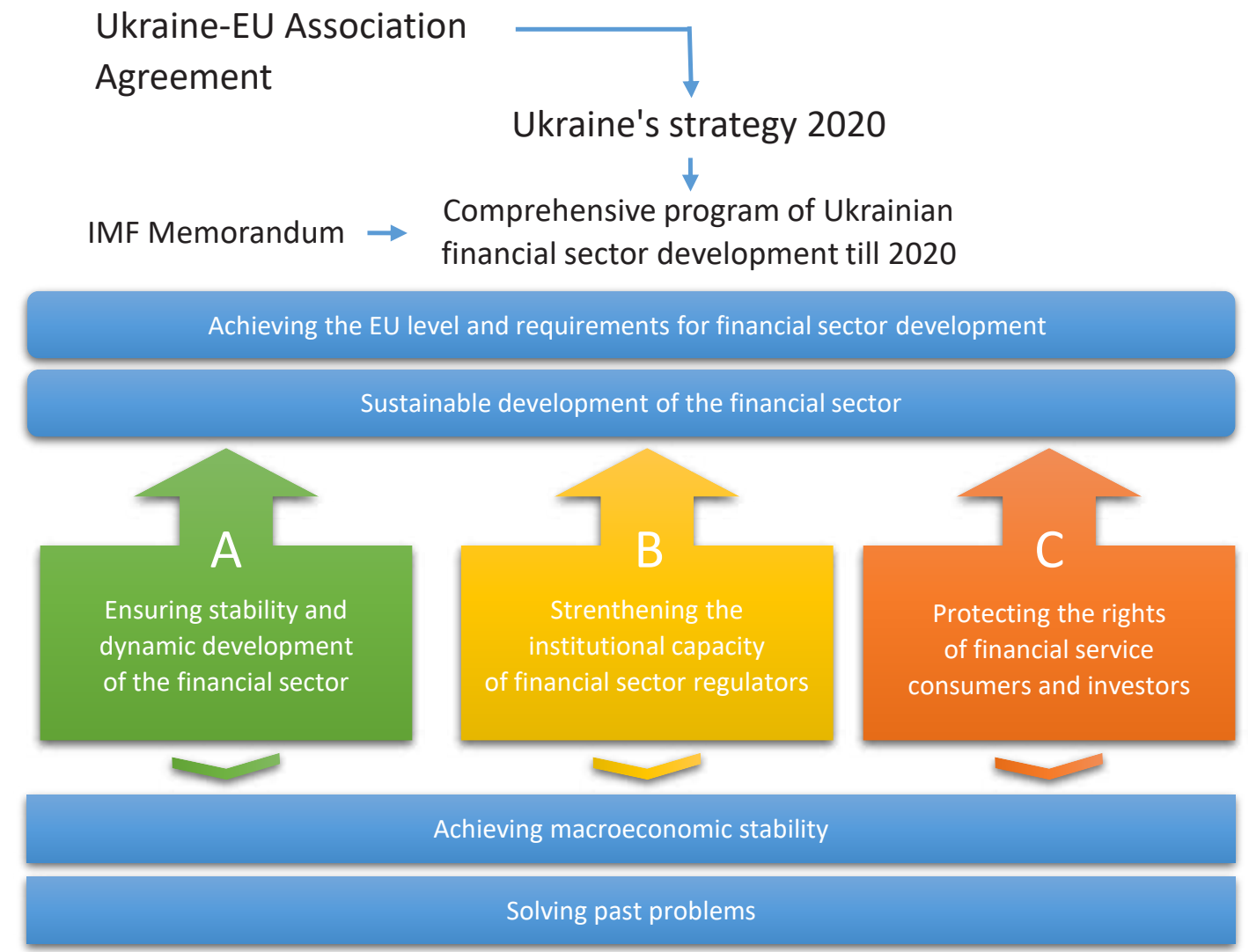

Note: NBU Resolution on Approval of the Comprehensive Program for the Development of the Financial Sector of Ukraine till 2020.

Figure 1. Comprehensive program measures 
Poliukhovych (2012) gives a classification of the NSSMC functions, which in our opinion is general, and can be applied both to the National Financial Services Commission and to the NBU, taking into account the specifics of the FSMs' sectors. In our opinion, if the implementation of normative activity and carrying out certain operations result in differences in the powers of state bodies, then supervision and control in the financial services market should be maximally harmonized, based on the solidarity of the capital market and the need to unify the transactions with financial institutions.

Today, there is a strong need for strengthening the interconnections between supervisory and regulatory bodies. In some EU countries, this need has led to the creation of a single state supervisory body that is responsible for activities in various financial sectors (Karachentseva \& Karachentsev, 2009).

Under European integration processes in Ukraine, the adaptation of legislation to European standards has begun. One of the steps is the adoption by the Verkhovna Rada of Ukraine on September 16, 2014, of the Law of Ukraine No. 1678-VII "On Ratification of the Association Agreement between Ukraine, on the one hand, and the European Union, the European Atomic Energy Community and their Member States, on the other hand".

This agreement has given rise to the beginning of the Ukrainian FSM reforming. The choice of a European model for the financial sector development in Ukraine, which could provide sustainable economic development and a competitive market environment, required a systematic solution to the accumulated problems, among which are the following: ensuring proper protection of the rights of consumers and investors of financial services; ensuring financial stability and dynamic development of financial services markets in Ukraine; and development of institutional capacity of Ukrainian FSMs' regulators. As a result, the Comprehensive Program for the Development of the Financial Sector of Ukraine until 2020 was adopted. The main measures are shown in Figure 1.

According to the program, the features of systemic problems in the financial sector of Ukraine are identified: a sharp increase in the proportion of problem assets in the balance sheets of banks - the share of problem loans in the banking sector increased from $12.9 \%$ in early 2014 to $24.7 \%$ at the end of the Q1 2015;

- significant outflow of deposits from the banking sector: - "-" $45.4 \%$ for 2014 and the Q1 2015 for foreign currency deposits, and - “-” 17.9\% for hryvnia deposits;

- tough administrative measures (including deposits withdrawal, currency exchange transactions) introduced in connection with the deployment of a military conflict and an economic crisis;

- high dollarization of loans and deposits $55.9 \%$ and $53.4 \%$, respectively, at the end of the Q1 2015;

unbalanced base of assets and liabilities of banks: the loans to deposits ratio reached a peak of $226.7 \%$ in 2009 and amounted to $158.8 \%$ at the end of the Q1 2015;

from the Q1 2014 to the Q2 2015, 47 banks, including one systemically important bank, were declared insolvent;

- insufficient size of own and regulatory capital of banks due to deterioration in the quality of loans and other assets and formation of reserves for active operations from the beginning of 2014;

exodus of large European players from Ukraine; after the 2008-2009 crisis, about 10 European banks sold their daughter banks in Ukraine or stopped their retail business;

the absence of initial public offering (IPO) of shares of Ukrainian companies on local and foreign exchanges during 2013-2014;

a decrease in the volume of trades on domestic exchanges (except government bonds) by $38 \%$ in 2014, to UAH 76 billion, including trading in stocks and derivatives by $46 \%$, to UAH 36 billion; 
Table 1. Implementation of the Comprehensive Program for the Development of the Financial Sector of Ukraine until 2020

\begin{tabular}{|c|c|c|c|c|}
\hline Indicator & Calculation & $\underset{2015}{\operatorname{January}} 1$, & $\begin{array}{l}\text { June } 1 \\
2017\end{array}$ & Plan for 2020 \\
\hline Consumer inflation & Consumer price index & $24.9 \%$ & $13.5 \%$ & $5 \% \pm 1 p p$ \\
\hline Foreign reserves level (USD bln) & - & 7.5 & 17.6 & $\begin{array}{l}\text { According to provisions of the } \\
\text { economic program within the } \\
\text { IMF Agreement on the Extended } \\
\text { Financial Mechanism (EFF) }\end{array}$ \\
\hline Level of cash in the economy & $\begin{array}{l}\text { According to the method, } \mathrm{MO}- \\
\text { to-GDP ratio }\end{array}$ & $17.8 \%$ & $14 \%$ & Not exceeding 9.5\% \\
\hline Cashless settlements level & $\begin{array}{l}\text { Share of cashless transactions } \\
\text { in the total volume of } \\
\text { transactions using payment } \\
\text { cards }\end{array}$ & $25.0 \%$ & $38.4 \%$ & $55 \%$ \\
\hline Number of POS-terminals & $\begin{array}{l}\text { Ratio of POS-terminals to } \\
\text { population (thousand units/ } \\
\text { mln people) }\end{array}$ & 4.7 & 5.4 & 11.0 \\
\hline $\begin{array}{l}\text { Level of loans and deposits } \\
\text { dolarization }\end{array}$ & According to the method & $46.1 \%$ & $46.2 \%$ & Under $40 \%$ \\
\hline $\begin{array}{l}\text { Level of nominal rates for new } \\
\text { loans in national currency }\end{array}$ & According to the method & $23.5 \%$ & $13.7 \%$ & Not exceeding $12 \%$ per annum \\
\hline Capital adequacy level & $\begin{array}{l}\text { According to Basel III } \\
\text { requirements }\end{array}$ & $15.6 \%$ & $12.7 \%$ & $8 \%$ or higher \\
\hline $\begin{array}{l}\text { Herfindahl-Hirschman } \\
\text { concentration index for assets }\end{array}$ & According to the method & 565.65 & 971.0 & 800 or higher \\
\hline $\begin{array}{l}\text { Loans-to-deposits ratio (gross } \\
\text { loans) }\end{array}$ & According to the method & $156 \%$ & $127 \%$ & Not exceeding $110 \%$ \\
\hline Level of insurance penetration & $\begin{array}{l}\text { According to the method, } \\
\text { share of GDP }\end{array}$ & $1.7 \%$ & $1.5 \%$ & $0.9 \%$ or higher \\
\hline Technical reserves of insurers & $\begin{array}{l}\text { Ratio of technical reserves of } \\
\text { insurers to GDP }\end{array}$ & $0.7 \%$ & $0.6 \%$ & $0.4 \%$ or higher \\
\hline Pension savings of population & $\begin{array}{l}\text { Ratio of pension savings of } \\
\text { population to GDP }\end{array}$ & $0.2 \%$ & $0.2 \%$ & $0.1 \%$ or higher \\
\hline $\begin{array}{l}\text { Assets of the } 2 \text { nd pillar of the } \\
\text { pension system }\end{array}$ & Assets-to-GDP ratio & $0 \%$ & $0 \%$ & - \\
\hline Public ICl assets & Public ICI assets-to-GDP ratio & $0.002 \%$ & $0.002 \%$ & $10 \%$ or higher \\
\hline
\end{tabular}

Note: Compiled based on NBU and Ukrainian Association of Investment Business data.

- low and unchanged share of insurance companies in the financial sector structure during $2008-2014$ - from $2.6 \%$ to $3 \%$ of the total - the low level of assets of the pension system at UAH $2.5 \mathrm{bln}$, or $0.2 \%$ of GDP at the end of 2014 .

Some data regarding the implementation of the Comprehensive Program for the Development of the Financial Sector of Ukraine until 2020 are shown in Table 1.

Positive trends in the financial sector can be observed, but the dynamics of individual indicators shows a lag behind the overall trend.

As part of the financial sector reform in Ukraine and the implementation of the "Comprehensive Program for the Development of the Financial Sector of Ukraine until 2020" developed by representatives of the financial and banking mar- ket regulators, the following issues are critical: reducing the number of state supervision bodies, deregulation and reducing the number of points of contact between business and the state, as well as the introduction of regulatory models with functions of controlling bodies in accordance with EU standards and the Association Agreement between Ukraine and the European Union.

It is urgent for Ukraine to create a single integrated mega-regulator, which would individually oversee and regulate the financial sector as a whole on the one-stop-shopping principle. Germany and Austria are an example. Many experts believe that future belongs to the integrated supervision that allows regulating closely related markets as a whole by applying effective approaches to risk analysis based on cross-sectoral micro-prudential and macro-prudential supervision. 
However, the creation of a mega-regulator is, today, a rather cardinal and virtually incredible step for Ukraine, since the NBU, the NSSMC and the National Financial Services Commission are not yet ready functionally for this. But even the first step regarding the distribution of functions of the National Financial Services Commission between the NBU and the NSSMC is a positive one towards consolidation and increasing the effectiveness of the financial sector supervision.

The draft law "On amendments to certain legislative acts of Ukraine regarding the consolidation of the state regulation functions of financial services markets" provides that the powers of regulation and supervision over insurance and leasing companies, credit unions and other non-bank creditors, credit bureaus, pawnshops and other financial institutions will be transferred to the NBU; and over non-state pension funds, issuers of mortgage certificates, funds for construction financing and real estate agencies - to the NSSMC. The indicated division of powers is quite logical in view of the regulatory actors and the respective regulators functionality.

It should be noted that the decrease in the number of regulators is always perceived by the business positively, as it uniquely leads to the unification of approaches and rules of regulation in the relevant markets.

In order to improve the system of FSM state regulation, it is necessary to formulate a procedure for assessing the regulators' performance, both central and territorial branches, which will make it possible to monitor the state regulation system both in separate regions and in Ukraine in general, taking all subjects' interests into account.

The quality of the state regulation influence involves determining the quality of the impact of state regulation on the financial market and its segments, as well as on functional shares: number of entities, capital adequacy, solvency, level of risk, etc.

It should be borne in mind that the main criterion among these is the level of activity of the FSM state regulation, as it characterizes the effective practical implementation of tools for direct influence of this mechanism. The level of state regula- tion activity $\left(L_{a}\right)$ is expedient to determine as the geometric mean of the growth rates of indicators, reflecting the intensity of the regulatory tools use. Taking into account the available statistics, such indicators are as follows: the number of regulatory documents developed and adopted by the relevant regulator, the number of licenses issued in the period of inspections, and impact measures taken according to these inspections' results. Consequently, the formula for the calculation is as follows (1):

$$
L_{a}=\sqrt[4]{T_{a} T_{l} T_{v} T_{i}}
$$

where $T_{a}$ - growth rate of the regulatory acts developed and adopted, $T_{l}$ - growth rate of the licenses issued, $T_{v}$ - growth rate of checks made, $T_{i}$ - growth rate of impact measures taken according to the checks' results.

At the same time, the level of government regulation can be characterized as active if the effective indicator is more than 1; if its value is less than 1 , then in this period there is a decline in activity in relation to state regulation of the financial services market. It should be noted that the calculation of this indicator plays an important role in the formation of state regulation policy, since it provides an opportunity to reconcile aspects such as the quality of government regulation and the level of the financial services market development. Unfortunately, today, when analyzing the development of the domestic financial services market, an indicator of the level of state regulation activity is not considered and is not taken into account, although it would provide fairly objective information on the frequency and effective use of a regulatory instrument. In order to calculate the level of the effectiveness of checks carried out for observance by the FSM subjects of the current legislation - the effective implementation of the control function - it is possible to use the ratio of impact measures taken to the number of checks (2):

$$
E_{c}=\frac{I}{V}
$$

where $E_{c}$ - effectiveness of the control function implementation, $I$ - number of impact measures taken, $V$ - number of checks made. 
Table 2. Application of instruments of the mechanism for state regulation of the financial services market in Ukraine for 2012-2016

\begin{tabular}{|c|c|c|c|c|c|c|c|c|c|}
\hline \multirow{2}{*}{ Type of regulation tool } & \multicolumn{5}{|c|}{ Year } & \multicolumn{4}{|c|}{ Growth rate $\%, 2016$ to } \\
\hline & 2012 & 2013 & 2014 & 2015 & 2016 & 2012 & 2013 & 2014 & 2015 \\
\hline \multicolumn{10}{|c|}{ Insurance market } \\
\hline Regulatory acts adopted & 5 & 2 & 4 & 8 & 5 & 0.00 & 150,00 & 25,00 & -37.50 \\
\hline Licenses issued & 110 & 204 & 168 & 260 & 248 & 125.45 & 21.57 & 47.62 & -4.62 \\
\hline Checks made & 65 & 138 & 138 & 32 & 68 & 4.62 & -50.72 & -50.72 & 112.50 \\
\hline Measures of impact implemented & 336 & 430 & 225 & 430 & 488 & 45.24 & 13.49 & 116.89 & 13.49 \\
\hline \multicolumn{10}{|c|}{ Market of services of financial companies } \\
\hline Regulatory acts adopted & 3 & 2 & 4 & 7 & 11 & 266.67 & 450.00 & 175.00 & 57.14 \\
\hline Licenses issued & 59 & 119 & 68 & 102 & 45 & -23.73 & -62.18 & -33.82 & -55.88 \\
\hline Checks made & 94 & 147 & 81 & 16 & 38 & -59.57 & -74.15 & -53.09 & 137.50 \\
\hline Measures of impact implemented & 317 & 195 & 483 & 71 & 93 & -70.66 & -52.31 & -80.75 & 30.99 \\
\hline \multicolumn{10}{|c|}{ Non-state pension support market } \\
\hline Regulatory acts adopted & 1 & 0 & 2 & 3 & 3 & 200.00 & - & 50.00 & 0.00 \\
\hline Licenses issued & 5 & 0 & 1 & 0 & 0 & -100.00 & - & -100.00 & - \\
\hline Checks made & 9 & 26 & 25 & 0 & 10 & 11.11 & -61.54 & -60.00 & - \\
\hline Measures of impact implemented & 24 & 13 & 25 & 1 & 4 & -83.33 & -69.23 & -84.00 & 300.00 \\
\hline \multicolumn{10}{|c|}{ Total for non-bank financial services market } \\
\hline Regulatory acts adopted & 9 & 4 & 10 & 18 & 19 & 111.11 & 375.00 & 90.00 & 5.56 \\
\hline Licenses issued & 174 & 323 & 237 & 362 & 293 & 68.39 & -9.29 & 23.63 & -19.06 \\
\hline Checks made & 168 & 311 & 244 & 48 & 116 & -30.95 & -62.70 & -52.46 & 141.67 \\
\hline Measures of impact implemented & 677 & 638 & 733 & 502 & 585 & -13.59 & -8.31 & -20.19 & 16.53 \\
\hline
\end{tabular}

Note: Compiled based on the annual reports of the National Financial Services Commission.

Based on the calculation of the effective implementation of the control function, it is possible to determine the appropriateness and effectiveness of supervisory activities by the relevant regulator. Control function effectiveness, taking into account that it helps to identify the facts of abuse, violation of the legislation in the field of money laundering, and the instrument of influence - to fill the budget, will be provided when the number of checks will be less than the number of impact measures taken, that is, this indicator should be more than 1 . This can be investigated through the example of one of the state regulators, in particular, the National Financial Services Commission. Output data for analysis are shown in Table 2.

As can be seen from the table, the largest number of normative legal acts developed and adopted by the State Commission for Regulation of Financial Services Markets was observed in 2016, due to the beginning of the crisis in the financial system. Thus, in 2016, 19 regulatory documents were adopted, which is almost twice as much as in 2012. Accordingly, the bulk of the Commission's legislative activity in 2016 was aimed at the market of services of financial companies. At the same time, the number of regulatory documents in the context of FSM segments varies depending on the peculiarities of their formation and development. With regard to licensing, the largest number of licenses was issued in 2015 - 362, which is explained by the high rate of development of the insurance market and the credit co-operation growth. In 2016, only 293 licenses were issued, which is almost $20 \%$ less than in the previous year. During the period under review, the largest number of inspections was carried out in 2013. This is primarily due to an increase in the level of control over the FSM subjects and the growing dynamics of increase in the volume of services provided by them. A fairly large number of violations detected in the financial services provision were observed in 2014, but in recent years the need for regulatory influence has diminished. So, in 2016, only 585 measures of influence were taken, which is almost 17\% less than in 2012. The decrease of this indicator is explained by the fact that the activities of state inspectors are aimed not only at identifying violations, but also providing explanations for their elimination and prevention. 
Table 3. Analysis of the state regulation activity of the Ukrainian FSMs and the effectiveness of the control function implementation in 2013-2016

\begin{tabular}{l|c|c|c|c|c|c|c}
\hline \multirow{2}{*}{\multicolumn{1}{c}{ Indicator }} & \multicolumn{3}{c|}{ Year } & \multicolumn{4}{c}{ Growth rate, 2016 to } \\
\cline { 2 - 8 } & $\mathbf{2 0 1 3}$ & $\mathbf{2 0 1 4}$ & $\mathbf{2 0 1 5}$ & $\mathbf{2 0 1 6}$ & $\mathbf{2 0 1 3}$ & $\mathbf{2 0 1 4}$ & $\mathbf{2 0 1 5}$ \\
\hline State regulation activity level & 0.42 & 0.37 & 0.39 & 0.22 & -47.22 & -39.19 & -42.39 \\
\hline \begin{tabular}{l} 
Control function effectiveness \\
\hline
\end{tabular} & 0.44 & 0.13 & 0.38 & 0.12 & -73.42 & -11.91 & -69.68 \\
\hline
\end{tabular}

The results of the calculations of the FSM state regulation activity in Ukraine and its control function effectiveness for the period 2012-2016 are presented in Table 3.

The study of the FSM state regulation activity shows that the activity of the FSM state regulation by the National Financial Services Commission after is rather low. So, if in 2013 the average growth rate of the Commission's activity in the main directions was 0.42 , then in 2016 it was only 0.22 . The control function effectiveness for the period under study is reduced, and in 2016 it is 0.12 , which is almost $70 \%$ less than in 2013. This trend is due to the formation and improvement of the relevant legislative and regulatory framework for the registration and licensing of financial market entities, the procedure for compiling and reporting; carrying out the appropriate advisory work on preventing violations of current legislation. Consequently, the entities of the financial services market themselves began to organize and carry out their activity more effectively, without allowing a significant breach of regulatory requirements.

An important role in assessing the effectiveness of the state regulation mechanism is played not only by the level of its activity and the control function effectiveness, but also by determining the quality of the influence of state regulation on the domestic FSM development.

With regard to the main trends in the development of financial services markets, which are controlled by the National Commission for the Regulation of Financial Services Markets, then the growth of the number of relevant market subjects, an increase in their assets and services rendered may be the main indicators of development.

Table 4 provides the main indicators for the financial services markets development for the 20122016 period.
The analysis of indicators in the context of financial services markets has shown that this segment has been dynamically developed. Thus, the number of financial institutions in 2016 amounted to 1,645 , which is $7 \%$ more compared with the beginning of the analyzed period. This tendency is due, in the main, to a significant FSM expansion. In total, the number of financial companies in 2016 is 650, which is twice as much as in 2012. The number of companies in other markets during the analyzed period decreased.

The number of insurance companies in the market decreased by $25 \%$ compared to 2012, and in 2016 it was 310 units. Total assets of insurance companies increased during the analyzed period, and in 2016 they were almost equal to the 2012 indicator. This is caused by a number of problems that hinder the insurance market development in Ukraine and do not provide for disclosure of its potential for economic growth. In particular, low interest in insurance, due to low solvency of the population; underdeveloped life insurance and health insurance; insufficient capitalization and low liquidity of insurers; low investment activity of insurance companies; distrust of insurers, etc.

In 2016, there were 64 non-state pension funds, and for the period under study their number decreased by almost $32 \%$. The analysis of quantitative indicators of non-state pension funds activity in Ukraine shows the gradual development of this segment, but quantitative growth at this stage of the NPF development is not accompanied by significant qualitative changes in the area of pension support for the population. After all, despite the fact that 15 years have passed since the legislative changes of 2003, the influence of this component of the pension system on the standard of living of pensioners is still low. Awareness of the population, low wages, distrust of citizens to such institutions, and shadow economy restrain further development NPFs in Ukraine. 
Table 4. Dynamics of main indicators of Ukrainian FSM development for 2012-2016

\begin{tabular}{|c|c|c|c|c|c|c|c|c|c|}
\hline \multirow{2}{*}{ Indicator } & \multicolumn{5}{|c|}{ Year } & \multicolumn{4}{|c|}{ Growth rate \%, 2016 to } \\
\hline & 2012 & 2013 & 2014 & 2015 & 2016 & 2012 & 2013 & 2014 & 2015 \\
\hline \multicolumn{10}{|c|}{ Insurance market } \\
\hline $\begin{array}{l}\text { Total number of } \\
\text { insurance companies, } \\
\text { units }\end{array}$ & 414.0 & 407.0 & 382.0 & 361.0 & 310.0 & -25.1 & -23.8 & -18.8 & -14.1 \\
\hline $\begin{array}{l}\text { Total assets of insurance } \\
\text { companies, UAH mln }\end{array}$ & 56224.7 & 66387.5 & 70261.2 & 60729.1 & 56075.6 & -0.3 & -15.5 & -20.2 & -7.7 \\
\hline $\begin{array}{l}\text { Net insurance premiums, } \\
\text { UAH mln }\end{array}$ & 20277.5 & 21551.4 & 18592.8 & 22354.9 & 26463.9 & 30.5 & 22.8 & 42.3 & 18.4 \\
\hline \multicolumn{10}{|c|}{ Market of services of financial companies } \\
\hline $\begin{array}{l}\text { Number of financial } \\
\text { companies, units }\end{array}$ & 312.0 & 377.0 & 415.0 & 571.0 & 650.0 & 108.3 & 72.4 & 56.6 & 13.8 \\
\hline Total assets, UAH mln & 36402.5 & 39781.2 & 51264.8 & 71120.0 & 67401.4 & 85.2 & 69.4 & 31.5 & -5.2 \\
\hline $\begin{array}{l}\text { Volume of services } \\
\text { provided, UAH mln }\end{array}$ & 41031.8 & 42342.9 & 54154.8 & 68282.3 & 110420.3 & 169.1 & 160.8 & 103.9 & 61.7 \\
\hline \multicolumn{10}{|c|}{ Non-state pension support market } \\
\hline $\begin{array}{l}\text { Number of non-state } \\
\text { pension funds, units }\end{array}$ & 94.0 & 81.0 & 76.0 & 72.0 & 64.0 & -31.9 & -21.0 & -15.8 & -11.1 \\
\hline $\begin{array}{l}\text { Total assets of funds, } \\
\text { UAH mln }\end{array}$ & 1660.1 & 2089.8 & 2469.2 & 1980.0 & 2138.7 & 28.8 & 2.3 & -13.4 & 8.0 \\
\hline $\begin{array}{l}\text { Pension contributions, } \\
\text { UAH mln }\end{array}$ & 1313.7 & 1587.5 & 1808.2 & 1886.8 & 1895.2 & 44.3 & 19.4 & 4.8 & 0.4 \\
\hline \multicolumn{10}{|c|}{ Non-bank lending market } \\
\hline $\begin{array}{l}\text { Number of loan } \\
\text { institutions, units }\end{array}$ & 708.0 & 739.0 & 711.0 & 728.0 & 621.0 & -12.3 & -16.0 & -12.7 & -14.7 \\
\hline Total assets, $\mathrm{UAH} \mathrm{mln}$ & 11648.8 & 15182.5 & 22110.8 & 26769.3 & 31963.1 & 174.4 & 110.5 & 44.6 & 19.4 \\
\hline $\begin{array}{l}\text { Volume of services } \\
\text { provided, UAH mln }\end{array}$ & 7694.8 & 9063.1 & 7862.7 & 11921.2 & 21707.6 & 182.1 & 139.5 & 176.1 & 82.1 \\
\hline \multicolumn{10}{|c|}{ Total for non-bank financial services market } \\
\hline $\begin{array}{l}\text { Number of financial } \\
\text { institutions, units }\end{array}$ & 1528.0 & 1604.0 & 1584.0 & 1732.0 & 1645.0 & 7.7 & 2.6 & 3.9 & -5.0 \\
\hline Total assets, UAH mln & 105936.1 & 123441.0 & 146106.0 & 160598.4 & 157578.8 & 48.7 & 27.7 & 7.9 & -1.9 \\
\hline $\begin{array}{l}\text { Volume of services } \\
\text { provided, UAH mln }\end{array}$ & 70317.8 & 74544.9 & 82418.5 & 104445.2 & 160487.0 & 128.2 & 115.3 & 94.7 & 53.7 \\
\hline
\end{tabular}

Note: Compiled based on the annual reports of the National Financial Services Commission.

The decrease in the number of subjects is observed in the credit cooperation market; accordingly, this indicator is 621, which is $12 \%$ less than in 2012. However, analyzing the increase in total assets and the volume of services provided, one can note the development of this sector of the non-bank financial services market. This trend is due to the potential boom of short-term consumer lending and especially lending on wages. In the absence of loans in the financial market, the crisis in the banking sector and the increased attention of the regulator precisely to the non-bank lending market, they received serious advantages in the consumer lending market. As a result, the activities of non-bank lending institutions specializing in short-term consumer lending became significantly more active.
Consequently, based on the above calculations, we will analyze the level of FSMs development, which are controlled by the National Commission for the Regulation of Financial Services Markets. In our opinion, a general development indicator can be presented as the geometric average of the growth rates of the number of FSM subjects, the value of their assets and the volume of services rendered:

$$
L_{d}=\sqrt[3]{R_{n s} R_{a} R_{p s}}
$$

where $L_{d}$ - integral indicator of FSMs development, $R_{n s}$ - growth rate of the number of FSMs subjects, $R_{a}$ - growth rate of the assets value, $R_{p s}$ - growth rate of the services provided.

Table 5 presents calculations. 
Table 5. Assessment of the Ukrainian financial market development in 2013-2016

\begin{tabular}{|c|c|c|c|c|}
\hline \multirow{2}{*}{ Indicator } & \multicolumn{4}{|c|}{ Value by years } \\
\hline & 2013 & 2014 & 2015 & 2016 \\
\hline Growth rate of number of financial market subjects & 1.1 & 1.0 & 1.0 & 0.9 \\
\hline Growth rate of assets value & 1.5 & 1.3 & 1.1 & 1.0 \\
\hline Growth rate of services provided & 2.3 & 2.2 & 1.9 & 1.5 \\
\hline Integral indicator of FSM development & 1.5 & 1.4 & 1.3 & 1.1 \\
\hline
\end{tabular}

Table 6. Dynamics of the development

$\left.\begin{array}{l:c}\hline \multicolumn{2}{c}{\text { Regression statistics }} \\ \hline \text { Multiple R } & 0.568673 \\ \hdashline \text { R Square } & 0.323389 \\ \text { Adjusted R } & -1.02983 \\ \begin{array}{l}\text { Square } \\ \text { Standard }\end{array} \\ \text { error }\end{array}\right)$

ANOVA

\begin{tabular}{l:c:c:c:c:c}
\hline Experiment & df & SS & MS & F & Significance F \\
\hline Regression & 2 & 0.000865 & 0.000433 & 0.238977 & 0.822564 \\
\hdashline Residual & 1 & 0.00181 & 0.00181 & & \\
\hdashline Total & 3 & 0.002675 & & & \\
\hline
\end{tabular}

\begin{tabular}{|c|c|c|c|c|c|c|c|c|}
\hline & Coefficients & Standard error & T-stat & P-value & Lower 95\% & Upper $95 \%$ & Lower $95.0 \%$ & Upper $95.0 \%$ \\
\hline Intercept & 1.177655 & 0.109865 & 10.71909 & 0.05922 & -0.21831 & 2.573626 & -0.21831 & 2.573626 \\
\hline $\mathrm{x} 1$ & -0.27984 & 0.411474 & -0.68009 & 0.619786 & -5.50811 & 4.948429 & -5.50811 & 4.948429 \\
\hline$\times 2$ & 0.129497 & 0.22024 & 0.587983 & 0.661613 & -2.66891 & 2.927906 & -2.66891 & 2.927906 \\
\hline
\end{tabular}

Figure 2 shows the dynamics of the development indicators of the Ukrainian financial market.

To find out how government regulation affects the level of financial services market development, we can use correlation-regression models.

In general, the stochastic dependence of the level of FSMs development on the influence of state regulation can be described by the following equation (4):

$$
y=1.177655-0.27984 x_{1}+0.129497 x_{2},
$$

where $y$ - level of FSMs development, units, $x_{1}-$ level of activity of FSMs' state regulation, units, $x_{2}$ - performance indicator of the control function of the state regulation, units.
Indicators of the significance of the obtained regression equation reveal that it represents $82 \%$ of the actual variation of the resultant change from the selected factors.

Interpretation of the obtained pairwise regression equation allows to conclude that the increase in the level of the state regulation activity by $1 \%$ leads to an increase in the level of FSMs development by $24 \%$. At the same time, the implementation of the control function by the authorities of the FSMs' state regulation according to statistical data discourages this sector development. Thus, the activity of FSMs' state regulation leads to a decrease in the integral indicator of the financial services market development by almost 3\%. 


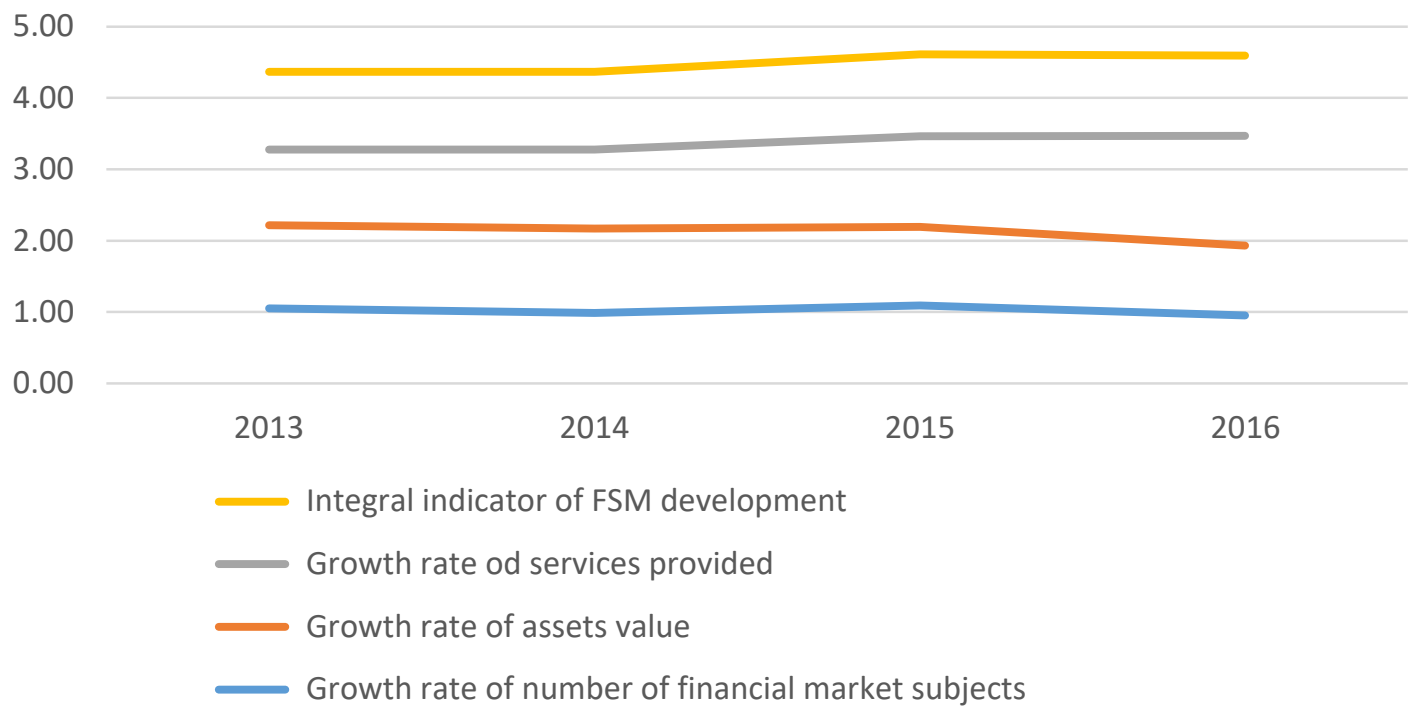

Figure 2. Dynamics of development indicators of the Ukrainian financial market for 2013-2016

\section{CONCLUSION}

Although Ukraine's current legislation on financial services is in line with the main EU standards, there are some pending issues along with a number of positive changes that have been made towards EU adaptation. Namely, inconsistency of state authorities' actions in the financial services markets concerning the implementation of control and supervision in the markets, and the absence of separate regulatory instruments. To solve these problems, it is necessary to introduce relevant institutions at the regional level, as well as to separate functions in a regulator that would be responsible for prudential supervision of financial services markets, as implemented in the EU countries.

The main factor enhancing the positive influence of state regulation on the financial services market development is the creation of appropriate conditions for increasing the activity indicators of such regulation. This implies further improvement of the regulatory and methodological framework for the creation, registration, licensing, provision of services, compilation and reporting, transparency of the financial institutions' activities and their interaction with consumers of financial services. As a result of this improvement, the need will decrease for conducting of control checks and implementing measures of influence, which neutralize the negative impact of low efficiency of state regulation on the development of the domestic financial services market.

\section{REFERENCES}

1. Andreikiv, T. Ya., \& Shmorhai, V. В. (2015). Сучасні механізми регулювання фінансового ринку в Україні [Suchasni mekhanizmy rehuliuvannia finansovoho rynku $\mathrm{v}$ Ukraini]. Tekhnologicheskiy audit $i$ rezervy proizvodstva, 1/7(21), 60-64 http://dx.doi.org/10.15587/23128372.2015.38751

2. Arkhipov A., \& Trynchuk V. (2017) Establishment and development of insurance supervision in Russia and Ukraine: retrospective review. Insurance Markets and Companies, 8(1),
48-58. http://dx.doi.org/10.21511/ ins.08(1).2017.05

3. Blicharz, R. (2009). Nadzór Komisji Nadzoru Finansowego Nad Rynkiem Kapitałowym w Polsce (364 p.). Rok.

4. Blyzniuk, O. P., \& Ivaniuta, O. M. (2017). Ринок фінансових постуг: навч. nociб. [Rynok finansovykh posluh: navch. posib.] (2nd ed.) (255 p.). Kharkiv: KhDUKhT.

5. COUNCIL REGULATION (EU) No 1092/2010 of 24 November 2010 on European Union macro- prudential oversight of the financial system and establishing a European Systemic Risk BoardBoard. Retrieved from http://www.esrb.europa.eu/shared/pdf/ESRBen.pdf?aa 560e12d90f1c1456c76f429ba5b05e

6. Davies, H., \& Green, D. (2008). Global financial regulation: the essential guide. Polity Press, Cambridge, UK.

7. Dodd-Frank Wall Street Reform and Consumer Protection Act, 2010. Retrieved from https://www.gpo. gov/fdsys/pkg/PLAW-111publ203/ 


\section{html/PLAW-111publ203.htm}

8. Karachentseva, T., \& Karachentsev, К. (2009). Национальное регулирование рынка финансовых услуг: инструменты, методы [Natsionalnoe regulirovanie rynka finansovykh uslug: instrument, metody]. Bankayski Vesnik, Liuty, 21-29.

9. Klimenko, V., Sokolova, A., \& Hasii, O. (2017). Status and prospects for the development of credit unions in Ukraine. Problems and Perspectives in Management, 15(4), 124-133. http://dx.doi.org/10.21511/ ppm.15(4).2017.11

10. Klymenko, О. V. (2014). Розвиток системи регулювання ринків небанківських фінансових послуг в Україні [Rozvytok systemy rehuliuvannia rynkiv nebankivskykh finansovykh posluh v Ukraini]. Ekonomika Ukrainy, 5, 58-69.

11. Levchenko, V., \& Ostapenko M. (2016). Information asymmetry on the market of non-banking financial services in Ukraine: causes, consequences, methods of control. Public and Municipal Finance, 5(1). https://doi.org/10.21511/ pmf.05(1).2016.04

12. Lobozynska, S. M. (2012). До питання створення мегарегулятора фінансового ринку в Україні та вдосконалення банківського регулювання [Do pytannia stvorennia meharehuliatora finansovoho rynku v Ukraini ta vdoskonalennia bankivskoho rehuliuvannia]. Retrieved from web. znu.edu.ua/herald/issues/2012/eco3-2012/194-199.pdf

13. NBU (2015). Постанова НБУ Про затвердження Комплексної програми розвитку фінансового сектору України до 2020 року [Postanova NBU Pro zatverdzhennia Kompleksnoi programy rozvytku finansovoho sektoru Ukrainy do 2020 roku]. Retrieved from http://zakon0.rada. gov.ua/laws/show/v0391500-15

14. Poliukhovych, V. I. (2012). Державне регулювання фондового ринку України: господарськоправовий механізм [Derzhavnе rehuliuvannia fondovoho rynku
Ukrainy: hospodarsko-pravovyi mechanizm] (337 p.). Kyiv: NDI pryvatnoho prava i pidpryiemnytstva.

15. Prawo rynku kapitałowego (2014). Komentarz. Seria: Duże Komentarze Becka. Wydanie: 2. Redakcja: prof. drhab. Marek Wierzbowski, dr Ludwik Sobolewski, dr hab. "Pawet Wajda. Rok. Retrieved from https:// www.ksiegarnia.beck.pl/autorzy/ pawel-wajda

16. Siomchenkov, O. A., \& Kuzmenko, A. V. (2012). Необхідність та шляхи реформування механізму державного регулювання фінансового ринку [Neobkhidnist ta shliakhy reformuvannia mekhanizmu derzhavnoho rehuliuvannia finansovoho rynku]. Retrieved from http://intkonf.org/ ken-somchenkov-oa-kuzmenkoav-neobhidnist-ta-shlyahi-reformuvannya-mehanizmu-derzhavnogoregulyuvannya-finansovogo-rinku/

17. Trade and Development Board. Commission on Trade in Goods and Services, and Commodities Expert meeting on trade and development implications of financial services and commodity exchanges. Report of the expert meeting on trade and development implications of financial services and commodity exchanges. Geneva, 3 and 20-21 September 2007.

18. USAID (2017). Регулювання ринку цінних паперів (досвід США, Великої Британії та Німеччини). Інформаційна довідка, підготовлена Європейським інформаційнодослідницьким центром на запит народного депутата України [Rehuliuvannia rynku tsinnykh paperiv (dosvid SShA, Velykoi Brytanii ta Nimechchyny). Informatsiina dovidka, pidhotovlena Yevropeiskym informatsiino-doslidnytskym tsentrom na zapyt narodnoho deputata Ukrainy]. Retrieved from http://euinfocenter.rada.gov.ua/ uploads/documents/29253.pdf

19. Wajda, P. (2009). Rola decyzji administracyjnej w nadzorze nad polskim systemem finansowym (377 p.). Seria: Monografie Prawnicze Rok.
20. Wierzbowski, M., \& Wiktorowska, A. (2009). Podstawowe Pojęcia Teoretyczne w nauce prawa administracyjnego. In M. Wierzbowski (Ed.), Prawo Administracyjne. Warszawa.

21. Закон "Про банки і банківську діяльність” від 7 грудня 2000 № 2121 [Zakon "Pro banky i bankivsku diialnist" vid 7 hrudnia 2000 No. 2121].

22. Закон "Про державне регулювання ринку цінних паперів в Україні” від 30 жовтня 1996 p. № 448 [Zakon “Pro derzhavne rehuliuvannia rynku tsinnykh paperiv v Ukraini" vid 30 zhovtnia 1996 r. No. 448].

23. Закон "Про НБУ” від 20 травня 1999 p. № 679 [Zakon "Pro NBU” vid 20 travnia 1999 r. No. 679].

24. Закон "Про цінні папери та фондовий ринок” від 23 лютого 2006 р. № 3480-IV [Zakon "Pro tsinni papery ta fondovyi rynok" vid 23 liutoho 2006 r. No. 3480-IV].

25. Нацкомфінпослуг (2016). Річні звіти Нацкомфінпослуг [Richni zvity Natskomfinposluh]. Retrieved from https://www.nfp.gov. ua/ua/Richni-zvity-Natskomfinposluh.html

26. Положення "Про Національну комісію з цінних паперів та фондового ринку", затверджене Указом Президента України від 23 листопада 2011 р. №1063 [Polozhennia "Pro Natsionalnu komisiiu $\mathrm{z}$ tsinnykh paperiv ta fondovoho rynku", zatverdzhene Ukazom Prezydenta Ukrainy vid 23 lystopada 2011 r. No. 1063].

27. Положення "Про Національну комісію, що здійснює державне регулювання у сфері ринків фінансових послуг”, затверджене Указом Президента України від 23 листопада 2011 p. № 1070 [Polozhennia “Pro Natsionalnu komisiiu, shcho zdiisniuie derzhavne rehuliuvannia u sferi rynkiv finansovykh posluh", zatverdzhene Ukazom Prezydenta Ukrainy vid 23 lystopada 2011 roku No. 1070]. 